\title{
Making Simple Repairs: Holes in the Wall ${ }^{1}$
}

Mary N. Harrison ${ }^{2}$

Landlords will deduct money from your security deposit if they have to fill in holes when you leave. You can save money by filling small holes yourself.

\section{Supplies Needed}

- Spackling compound (small can of ready-to-use compound to fill small holes).

- Patching plaster (powder that is to be mixed with water to form a "paste" to fill holes).

- A putty knife or a dinner knife.

-Sandpaper-medium grit.

- Old cloth or small paintbrush.

\section{How To Fix}

A. Small holes (cracks, nail holes, and other holes up to about an inch in diameter.)

1. Remove any lose or uneven plaster.

2. Put a small amount of spackling compound or patching plaster on the hole or crack.
3. With your finger work the compound into the hole or crack. Pull the straight edge of a putty knife or block across the compound to make it smooth.

\section{B. Large holes}

1. Remove any loose plaster. Smooth the edges of the hole with a knife (If the hole is too large, fill behind the hole with wadded newspaper.)

2. Partially fill the hole with spackling compound or patching plaster. Let it dry.

3. Add a second batch of compound or plaster. Let it dry.

4. Continue layering compound or plaster and allowing it to dry until the hole is completely filled.

5. When the patch is completely dry, sand it gently until it is smooth and even.

1. This document is FCS5234-02, one of a series of the Department of Family, Youth and Community Sciences, Florida Cooperative Extension Service, Institute of Food and Agriculture Sciences, University of Florida. Publication: May 2002. Revised: December 2005. Please visit the EDIS Web site at http://edis.ifas.ufl.edu.

2. Mary N. Harrison, professor, Department of Family, Youth and Community Sciences, Cooperative Extension Service, Institute of Food and Agricultural Sciences, University of Florida, Gainesville, 32611.

The Institute of Food and Agricultural Sciences (IFAS) is an Equal Opportunity Institution authorized to provide research, educational information and other services only to individuals and institutions that function with non-discrimination with respect to race, creed, color, religion, age, disability, sex, sexual orientation, marital status, national origin, political opinions or affiliations. U.S. Department of Agriculture, Cooperative Extension Service, University of Florida, IFAS, Florida A. \& M. University Cooperative Extension Program, and Boards of County Commissioners Cooperating. Larry Arrington, Dean 